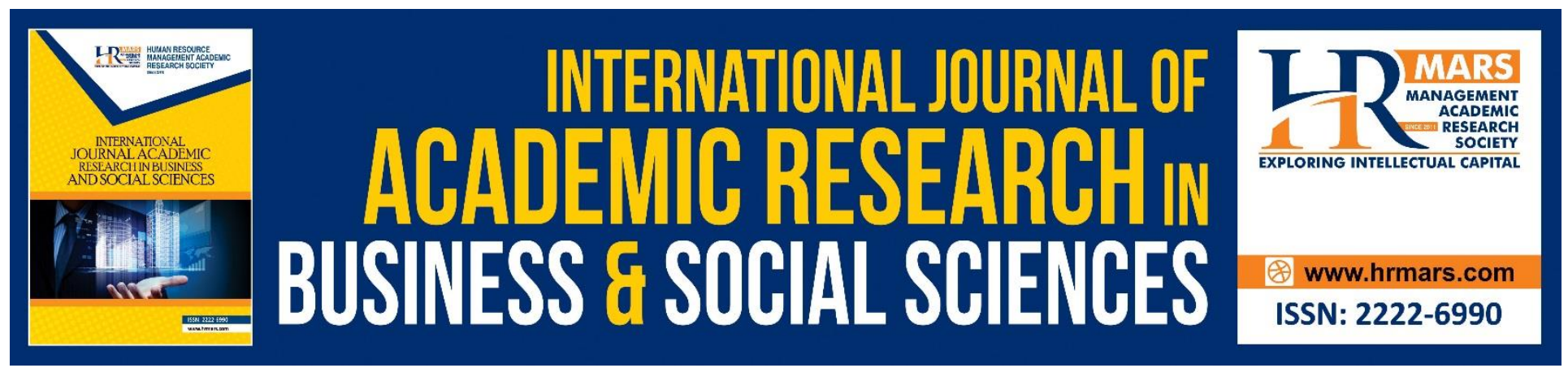

\title{
The Influence of Knowledge Management on Leadership Methods in Islamic Institution: A Conceptual Review
}

Mohamad Nizam Yusof, Zahri Hamat, Nurhidayah Marzuki@Yahaya, Norafzan Awang \& Wan Syukry Wan Drani

To Link this Article: http://dx.doi.org/10.6007/IJARBSS/v10-i10/8017 DOI:10.6007/IJARBSS/v10-i10/8017

Received: 27 August 2020, Revised: 25 September 2020, Accepted: 22 October 2020

Published Online: 20 October 2020

In-Text Citation: (Yusof, et al., 2020)

To Cite this Article: Yusof, M. N., Hamat, Z., Marzuki@Yahaya, N., Awang, N., \& Drani, W. S. W. (2020). The Influence of Knowledge Management on Leadership Methods in Islamic Institution: A Conceptual Review. International Journal of Academic Research in Business and Social Sciences. 10(10), 859-864.

Copyright: (C) 2020 The Author(s)

Published by Human Resource Management Academic Research Society (www.hrmars.com)

This article is published under the Creative Commons Attribution (CC BY 4.0) license. Anyone may reproduce, distribute, translate and create derivative works of this article (for both commercial and non-commercial purposes), subject to full attribution to the original publication and authors. The full terms of this license may be seen

at: http://creativecommons.org/licences/by/4.0/legalcode

Vol. 10, No. 10, 2020, Pg. 859 - 864

Full Terms \& Conditions of access and use can be found at http://hrmars.com/index.php/pages/detail/publication-ethics 


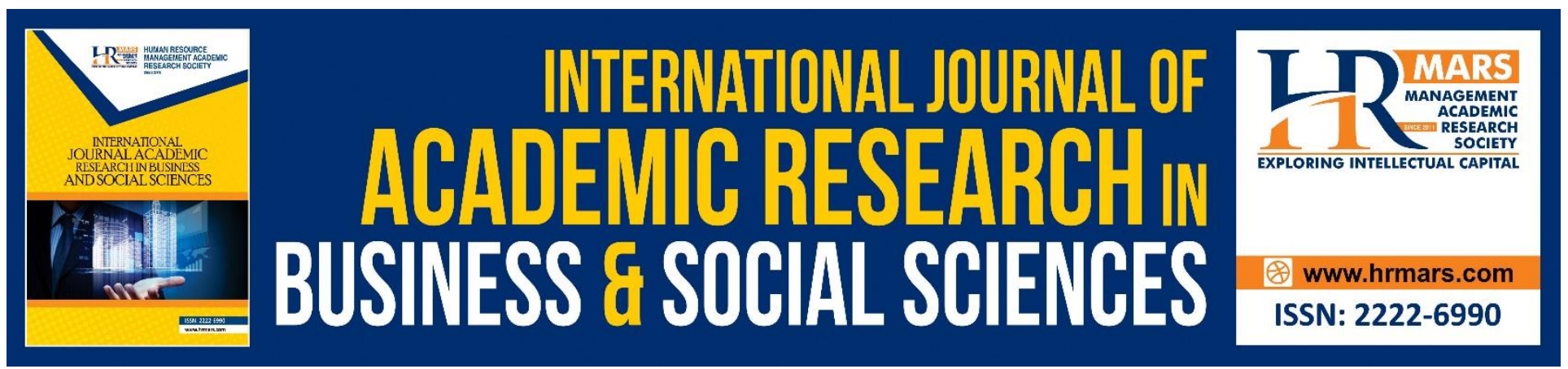

\title{
The Influence of Knowledge Management on Leadership Methods in Islamic Institution: A Conceptual Review
}

\author{
Mohamad Nizam Yusof ${ }^{1}$, Zahri Hamat ${ }^{2}$, Nurhidayah \\ Marzuki@Yahaya ${ }^{3}$, Norafzan Awang $^{2}$ \& Wan Syukry Wan Drani ${ }^{2}$ \\ ${ }^{1}$ Faculty of Informatics Science, ${ }^{2,4}$ \& ${ }^{5}$ Faculty of Economics and Management, ${ }^{3}$ Faculty of Islamic \\ Studies, University College Bestari, Setiu, Terengganu \\ ${ }^{1}$ Email: nizam@ucbestari.edu.my
}

\begin{abstract}
The purpose of this paper is to study the influence of knowledge management on leadership methods in Islamic institutions. Knowledge is a vital resource for the organization especially for leaders. However, not all leaders practice knowledge management in their institutions. As a leader, knowledge management is an essential mechanism to achieving the goal and direction of an institution. In Islamic institutions, some of the leaders are still facing challenges in managing their staffs as there are issues with the performance of staffs such as lack of commitment to work, corruption, low productivity, indiscipline and so on. Thus, knowledge management practices are important for the institution to gain benefit from utilization of organizational knowledge. Improper in managing this valuable resource will result a loss of valuable knowledge that available in the mind of leaders. The situation will be worse when the leaders relocate, resign, and retire. The question is, does the leader implement knowledge management in Islamic institutions? How does the leader implement knowledge management practices in their institution? This paper comprehensively reviews the concept of knowledge management on leadership methods in Islamic institution.
\end{abstract}

Keywords: Knowledge Management, Leadership, Islamic Institution, Performance, Management Practices

\section{Introduction}

The implementation of knowledge management (KM) in the organization had become important strategy to the organization including Islamic Institutions. Nowadays, most of the institutions aware of their organizational knowledge as an asset that can be transform into organization's benefit. In Islam, knowledge plays a vital role in the formation of human civilization. The importance of knowledge can be seen in the first revelation of Quran verses, the Surah Al-Alaq to the Prophet Muhammad that encourages the Muslims to read and recite. Previous researchers found that the organization which manages knowledge systematically and properly had improved 
INTERNATIONAL JOURNAL OF ACADEMIC RESEARCH IN BUSINESS AND SOCIAL SCIENCES Vol. 10, No. 10, 2020, E-ISSN: 2222-6990 @ 2020 HRMARS

the organization performance in terms of financial, innovation and competitive advantages. Moreover, managing knowledge is becoming an important strategy because it's can influence the organization to remain active in today's challenges business environment.

Every organization has a firm aspiration to grow in today's competitive environment. In Islamic institutions, organization facing challenges in managing their staffs as there are an issue with the performance of staffs such as lack of commitment to work, corruption, low productivity, indiscipline and so on. These issues might affect the performance of the organization. There might be a quite great number of practices that can be applied to solve the issues; however, the best solution is through the best leadership practices by the leaders. Leader is the important person that a responsible to the performance of the organization and plays an important role in determining the desired management pattern and direction for an organization. In this knowledge era, the knowledge and experience of the leaders becomes the organization's greatest weapon to the organizations (Rasli et al., 2004).

Evidently, majorities of studies in knowledge management discipline found that knowledge is an important resource for the organizational performance. However, in Islamic institution, the implementation of knowledge management mechanism is still at infancy level. To be a good leader, a person should have a relevant knowledge and experience to enable them to successful manage and motivate the employees. A leader cannot get the knowledge automatically. There is a strategy to acquire the knowledge and for time being it is through the knowledge management practices. However, there has been a little research done to explore the relationship between knowledge management and leadership especially in Islamic institution. Thus, at preliminary study, it is significant to comprehensively review the literature relating to the concept of leadership methods and knowledge management in Islamic Institution.

\section{Literature Review}

\section{Knowledge Management}

In this intellectual age, knowledge has become a central force behind the success of organizations. However, ineffectiveness managing the knowledge makes it invaluable to organizations. Knowledge management was introduced more than two decades ago to help companies create, share, and use knowledge more systematically. Knowledge management can be defined as the identification, optimization, and active management of intellectual assets to create value, increase productivity, and gain and sustain competitive advantage (Nonaka \& Takeuchi, 1995). It can also be defined as the process of identifying/creating, assimilating, and applying organizational knowledge to exploit new opportunities and enhance organizational performance. Gold et al., (2001) define knowledge management process as a structured coordination for managing knowledge effectively. There are no universally accepted in the process of knowledge management. Prior researchers have identified several key aspects of the knowledge management process in their study. The common process of knowledge management includes knowledge acquisition, knowledge conversion, knowledge application and knowledge protection. Thus, the knowledge can be stored, shared, protected and has its own value for use in the organization (Rahman, Yunus, \& Kadir, 2017). 
INTERNATIONAL JOURNAL OF ACADEMIC RESEARCH IN BUSINESS AND SOCIAL SCIENCES Vol. 10, No. 10, 2020, E-ISSN: 2222-6990 @ 2020 HRMARS

\section{Leadership Practices}

A leader is a person who sets the tone and culture in an organization. An effective leader is a person that can unify his or her followers by altering their views and motivation to meet the organization's need without compromising the needs of the followers. A clear distinction exists between managers and leaders. Managers create order and consistency, whereas leaders are interested in the direction, vision, goals, objectives, intention, purpose, and effectiveness of actions to produce change and to motivate their employees (Bennis \& Townsend, 2005).

Various authors provided different meanings of leadership in previous literature. For instance, leadership has been defined as a position, personality, responsibility, influence process, or an instrument to achieve a goal or behavior (Renata et al., 2018). Leadership can also be defined as a dynamic process in which one individual influence other to contribute to the achievement of the team's task (Neck et al., 2006). In Islamic context, leadership encompasses the leadership of himself as a servant of Allah SWT by directing himself to the good, fulfilling the trust of the Creator, mankind and the environment (Naquib, 1993). Therefore, a good leader hopefully can bear this responsibility for the sake of Allah, he cannot see the material life or what he will receive from the people, and he must see it as fulfilling the command of Allah (SWT) and as what the Prophet commanded us to do (Abdulganiyu, Gbate, \& Kaita, 2019).

Leadership is a main element in determining the direction and performance of the organization. However, a quality of leadership is not only measure bases on products and services achievement but also on knowledge and experience of the leader. Therefore, in Islamic Institution the elements of Islamic values and knowledge need to be applied and practiced by leaders so that the performance of the institution is also viewed from an Islamic perspective.

\section{Knowledge Management and Method of Leadership Methods}

Leadership methods are an approach that implemented by leaders to influence their members to achieve organizational performances. Leaders will try to influence the employees to perform their tasks to achieve the goals and direction of the organization. Mohd \& Hassan (2011) has listed four key elements seen to influence leadership in quality management. The four elements are knowledge and skills, commitment, communication, and humanity.

Every organization needs a good leader to manage and monitor organization's members. The leader must have good leadership characteristics to motivate people involving in the organization's vision and development process. Knowledge and skills of the leader are the vital element that makes a leader differs from other. In any organization, leaders have direct impact on the performance of their subordinate and organization.

\section{Islamic Institution}

Islamic institution in this paper refers to organizations that manage the institution based on Islamic principles. Ahmad (2010) provides the definition of Islamic Institution as an institution that operates their organization within the principles of Islam in any activities that encompasses various aspects. The nature of Islamic institution is to deal with Shariah compliant activities. Shariah refers to the sum of Islamic teaching and system, which was revealed to Prophet Muhammad (P.U.B.H) recorded in the 
INTERNATIONAL JOURNAL OF ACADEMIC RESEARCH IN BUSINESS AND SOCIAL SCIENCES Vol. 10, No. 10, 2020, E-ISSN: 2222-6990 @ 2020 HRMARS

Quran and deducted from the Sunna (Kamri, 2007). As long as the product or service is compliant to all the requirements of Shariah, the product or service is deemed permissible in Islam and acceptable for Muslims.

\section{Research Model}

Method of leadership is an importance element that applied by the leaders to influencing their staffs for achieve the organization's vision and mission. Knowledge has been approved as a valuable source for the organizations in improving their business activities. However improper managing knowledge will lead the organization missing this asset. Referring to Figure 1, this paper suggested a study of relationship between knowledge management and method of leadership for Islamic Institution. The research model predicts influence of knowledge management practice and method of leadership. The research model might be empirically test to see the correlation between those variables.

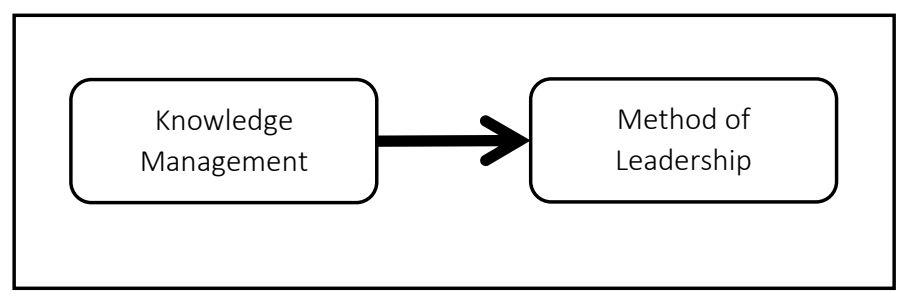

Figure 1: Research Model

\section{Conclusion}

Leadership is one of the factors that might influences leader to enhance institution's performance. Knowledge management can be practiced by the leader for organization's excellence. There are several studies shown that knowledge management significantly related with leadership in effectively managing organization. Most of researchers agreed that knowledge management is a vital role of leaders, especially for the top management (Bell et al., 2004). The prime reason for organizations to focus on knowledge management is that knowledge is regarded as the driving force for the organizations of the future. Study shown that the Islamic approaches in leadership methods in Malaysian Islamic Institution is at moderate level (Ahmad, 2010; Marzuki@Yahya, 2017) and most of Islamic institution still practice conversational method in their organization although leaders understood that Islamic approaches is the best practice method for the institution This is because Islamic institutions have placed more emphasis on the physical aspect, rather than the spiritual aspect (Johari \& Ahmad, 2019). Thus, preliminary this paper comprehensively reviews the concept of knowledge management on leadership methods in Islamic institution and could be a reference for further study in this critical field.

\section{References}

Abdulganiyu, B., Gbate, N. A., \& Kaita, S. I. (2019). Good Leadership and Good Governance in Nigeria: An Islamic Perspective. International Journal of Academic Research in Business and Social Sciences, 9(8), 461-470.

Ahmad, F. A. (2010). Kaedah pengurusan institusi-institusi pembangunan berteraskan Islam di Malaysia. Shah Alam: Pusat Penerbitan Universiti (UPENA). 
INTERNATIONAL JOURNAL OF ACADEMIC RESEARCH IN BUSINESS AND SOCIAL SCIENCES

Vol. 10, No. 10, 2020, E-ISSN: 2222-6990 @ 2020 HRMARS

Bell DeTienne, K., Dyer, G., Hoopes, C., \& Harris, S. (2004). Toward a model of effective knowledge management and directions for future research: Culture, leadership, and CKOs. Journal of leadership \& organizational studies, 10(4), 26-43.

Bennis, W. G., \& Townsend, R. (2005). Reinventing leadership: Strategies to empower the organization. Harper Collins.

Gold, A. H., Malhotra, A., \& Segars, A. H. (2001). Knowledge management: An organizational capabilities perspective. Journal of management information systems, 18(1), 185-214.

Johari, F. F., \& Ahmad, F. A. (2019). Islamic-Based Development Focus in the Mission Statements of Islamic Institutions in Malaysia. International Journal of Academic Research in Business and Social Sciences, 9(11), 686-694.

Kamri, N. (2007). Pelaksanaan kod etika berteraskan Islam di institusi pembangunan berteraskan Islam: Kajian Kes di Lembaga Tabung Haji. Tesis Ijazah Doktor Falsafah yang diserahkan kepada Pusat Pengajian Sains Kemasyarakatan, Universiti Sains Malaysia. Tidak diterbitkan.

Marzuki@Yahaya, N. (2017). Kaedah Kepimpinan Dan Perancangan Strategik Dalam Pengurusan Kualiti Di Institusi Pembangunan Berteraskan Islam Brunei Darussalam. Master's thesis submitted to the School of Social Sciences, Universiti Sains Malaysia. Not published.

Mohd, A., \& Hassan, A. (2011). Gaya kepimpinan di tempat kerja. Utusan Publication \& Distributors Sdn. Bhd.

Naquib, A. S. M. (1993). Islam and secularism. Kuala Lumpur: Muslim Youth Movement of Malaysia (ABIM).

Neck, C. P., Bligh, M. C., Pearce, C. L., \& Kohles, J. C. (2006). The importance of self-and shared leadership in team-based knowledge work. Journal of managerial Psychology.

Nonaka, I., \& Takeuchi, H. (1995). The knowledge-creating company: How Japanese companies create the dynamics of innovation. Oxford university press.

Rahman, M. A., Yunus, M. A., \& Kadir, I. K. A. (2017). Implementing Knowledge Management in Biro Tatanegara, Malaysia: BTN Staff's Perception. International Journal of Academic Research in Business and Social Sciences, 7(12), 461-470.

Rasli, A., Madjid, M. Y., \& Asmi, A. (2004). Factors that influence implementation of knowledge management and information technology infrastructure to support project performance in the construction industry, International Business Management Conference, Universiti Tenaga Nasional, pp. 62-70.

Renata, R., Wardiah, D., \& Kristiawan, M. (2018). The Influence of Headmaster's Supervision and Achievement Motivation on Effective Teachers. International Journal of Scientific \& Technology Research, 7(4), 44-49. 